\title{
Generic drug manufacturers lose patent protection battle
}

London

IN the conflict between the originators of new drugs and the manufacturers of generic copies of the originals, the originators are about to score a significant victory. Next week a change in patent law will give certain drugs, including some of the world's most successful, an extra four years of protection in Britain from generic competitors. The orginators say this will strengthen the industry as a whole; they argue that better patent protection increases confidence in the industry and as a result increases investment. And they claim that increased patent life is necessary to ensure recovery of the increasing costs of research. Although it may damage the generics industry in the short term, in the long it will be beneficial, they say.

But independient companies claim that

\section{Use of fetal tissue deemed acceptable \\ Washington}

A SPECIAL panel convened to answer questions about research using human fetal tissue last week concluded that although "it is of moral relevance" if the tissue is obtained from induced abortions, nevertheless "the use of such tissue is acceptable public policy".

The Human Fetal Tissue Transplantation Research Advisory Panel was formed at the request of the US Health and Human Services Assistant Secretary Robert Windom, who placed a moratorium on federal funding for fetal tissue research using material from induced abortions pending the outcome of the panel's deliberations. The panel began work last month, but recessed after two days of discussion without reaching agreement on precise language for answering the secretary's questions.

The panel took pains not to take a moral stand on the contentious issue of abortion, instead concluding that so long as abortion was legal, then cadaverous tissue obtained from aborted fetuses could legitimately be used for research. Opponents of abortion had argued that expanding the use of fetal tissue would encourage women to have abortions, but the panel concluded that there was no evidence that use of fetal remains for research had had "a material effect on the reasons for seeking an abortion in the past".

The panel's recommendations will be presented to James Wyngaarden, director of the National Institutes of Health, at the directors' advisory meeting on 1 December, and Wyngaarden will transmit them to the assistant secretary. the industry will be severely hit; some smaller companies may not survive. In addition, it is claimed that between $\mathfrak{f 5 0}$ and $£ 100$ million may be added to the National Health Services medicines bill And despite an independent review which said the repeal of the proviso was not justified on the grounds of increased investor confidence and which documented the substantial extra cost to the National Health Service, the government decided for the repeal. It will remove a proviso in the 1977 patents act which has irritated the mainstream pharmaceutical companies for several years. When patent protection for drugs in Britain was increased from 16 to 20 years in 1977 , nobody noticed a proviso which, for certain drugs, effectively took back the extra four years the act granted.

It meant that for products under patent protection at the time of the act, and with more than five years of patent life to run, other companies could apply for a licence to use the patent during the extra four years granted, providing that royalties were paid to the originator. Patents filed after introduction of the new act were unaffected by that proviso, so it was destined to become obsolete in the $1990 \mathrm{~s}$, leaving a four-year 'product vacuum' as it was phased out. The imminent repeal of the proviso, which was hotely debated earlier this year, brings this 'vacuum' forward by five years. The generic equivalents of Zantac (Glaxo) and Zovirax (Wellcome) for example, were due to become available in 1993 and 1991, respectively. Now availability will be delayed until 1997 and 1995. A study by Martin Paltnoi Associates, a British consultancy which specializes in drug patents, says that about 50 drugs will be affected.

The Association of the British Pharmaceutical Industry has been lobbying for the repeal for several years. It claims that poor patent protection in Britain makes it relatively unattractive compared to its international competitors. In Britain, about 12 years of patent life is taken up in getting the product to the marketplace, leaving only eight years of protection, of which half were lost for many products as a result of the licence proviso.

Canada and the United States are increasingly seen to be more attractive to investors because of their patent law, say the British manufactuers. In Canada, a law passed last year allows drug patent holders 10 years of exclusive marketing rights. In exchange, the industry promises to double research spending within 10 years. In the United States, a law passed in 1984 allows manufacturers to apply for an extension of the patent life of 17 years to

\section{AIDS reagent repository opens}

\section{Washington}

AFTER years of preparations, an AIDS reagent repository containing deposits from AIDS researchers world-wide has been opened by the US National Institute of Allergy and Infectious Diseases (NIAID). The repository contains over 100 reagents, virus stocks, cell lines and clones drawn from contributions solicited from nearly 1,500 researchers.

The repository was established in April of this year through the efforts of John McGowan, chief of the Developmental Therapeutics Branch of NIAID's AIDS programme. McGowan says the two aims of the repository are to make reagents freely available to draw in new researchers to study AIDS, and to offer standardized protocols and reagents so that results can be compared between laboratories.

The NIAID repository is part of the World Health Organization AIDS reagent repository programme, and is collaborating with similar repositories in Paris and London. The repository's reagents are free to industry, government and academic researchers, to be used for research purposes only.

Carol Ezzell

\section{Magellan damage}

\section{Washington}

THE Magellan spacecraft, scheduled to be launched towards Venus in April next year, suffered only minor damage when an electrical fire occurred on 17 October as it was being set up for testing at the Kennedy Space Center, Florida. The fire was caused when wires connecting an external battery touched each other, and was extinguished within a minute. Project scientist Steve Saunders said last Monday that after visible damage had been cleaned up, tests showed that the spacecraft's signal processing units were unscathed. The only concern, he said, was the loss of ten days' time from the launch schedule, although this does not immediately jeopardize the launch date.

David Lindley

compensate for time taken seeking regulatory approval. This law is presently being tested; it is being disputed whether time spent on research and development can count as time spent seeking regulatory approval. On the introduction of that law, the generic sector was compensated by being permitted to carry out research during the patent life of the product.

Jorge Goldstein, a US patent lawyer, described an unexpected spin-off from that law: aeroplane manufacturers are now claiming that patent lifetime of their products is absorbed by the time spent seeking approval of the Federal Aviation Authority. But such claims are unlikely to succeed, he says. Christine McGourty 